\title{
Customer Relations Management sebagai Salah Satu Upaya Public Relations Perusahaan Jasa Perbankan Menciptakan Good Image
}

\author{
Prima Ayu Rizqi Mahanani \\ Dosen Prodi Komunikasi Islam, Jurusan Ushuluddin dan Ilmu Sosial \\ STAIN Kediri
}

\begin{abstract}
Abstrak
Artikel ini membahas tren pemasaran di abad 21yang bergeser dari pendekatan transaksional ke pendekatan relasional dengan fokus pada pemenuhan kebutuhan, kepuasan, dan kesenangan yang berpengaruh pada pelanggan bisnis. Peta bisnis jasa layanan perbankan memiliki tuntutan yang berubah-ubah sehingga humas dituntut kreativitasnya dalam memberikan pelayanan terbaik kepada pelanggan mendapatkan gambar yang baik. Konsep layanan menggunakan paradigma layanan terkemuka untuk menumbuhkan kekuatan pelanggan berdasarkan pelanggan berorientasi kepuasan, banyak digunakan oleh layanan perbankan bisnis saat ini. Paradigma yang fokus pada bagaimana memberikan layanan kepada pelanggan sehingga pelanggan merasa puas. Keterampilan untuk memahami dan memenuhi harapan pelanggan harus filosofi bisnis setiap perusahaan layanan perbankan dan manajemen hubungan pelanggan adalah strategi
\end{abstract}

Kata kunci: manajemen hubungan pelanggan, humas, citra baik

\section{Abstract}

This article deals with marketing trends in the 21st century is shifting from a transactional approach to the relational approach with focus on the fulfillment of needs, satisfaction, and pleasure affect business banking customers are very dependent on the customer. Map business services banking services fickle demands creativity public relations in providing the best service to its customers get a good image. Service concept using the service paradigm leading to cultivate the power of the customer based on the customer satisfaction-oriented, widely used by business banking services at this time. Paradigms that focus on how to provide services to the customer so that the customer was satisfied, beyond what can be given to something that is important and not to be underestimated. Skills to understand and fulfill customer expectations should be every company's business philosophy of banking services and customer relationship management is a strategy

Keywords: customer relations management, public relations, good image

\section{Pendahuluan}

Perusahaan jasa perbankan berbeda dengan perusahaan manufaktur yang mengolah bahan mentah menjadi bahan baku sampai menjadi hasil jadi. Bisnis jasa perbankan merupakan kinerja keuangan yang mengutamakan pelayanan yang baik dan memupuk customer (pelanggan). Bank bekerja pada prinsip kepercayaan yang bertumpu pada customer yang merupakan nafas perusahaan. Persaingan bisnis perbankan yang kompetitif lebih mengandalkan pada kualitas pelayanan, selain menawarkan beragam produk yang berbau teknologi informasi. Berbeda dengan perusahaan manufaktur yang lebih pada penyediaan produk yang disesuaikan dengan permintaan pasar. 
Pernyataan di atas diperkuat dengan pendapat Rosady Ruslan dalam bukunya manajemen humas dan manajemen komunikasi yang mengatakan bahwa industri jasa perbankan sangat "sensitif" dengan masalah kepercayaan, kualitas pelayanan dan citra (Ruslan, 2001:71). Misalnya ketika terjadi krisis kepercayaan nasabah terhadap pelayanan dunia bisnis perbankan, dan dampaknya akan terjadi rush (penarikan dana dalam jumlah besar oleh nasabahnya secara serentak). Adapun saat ini puluhan bank telah dilikuidasi dan melakukan merger antar bank sebagai jalan penyelamatan, baik bank milik pemerintah dan bank swasta.

Kebutuhan masyarakat yang terus berkembang dan teknologi informasi yang semakin canggih menuntut pihak perbankan harus terus melakukan perbaikan kinerja, restrukturisasi organisasi dan redefinisi kepentingan bisnis agar mampu bersaing dengan tangguh dan tetap eksis. Kompetisi antar bank semakin ketat tatkala produk yang ditawarkan bank dirasakan sama oleh masyarakat. Tidak ada yang membedakan, yang membedakan adalah soal pelayanan (service) kepada nasabah.

Sekarang ini nasabah menyimpan uang di bank dipengaruhi oleh kualitas pelayanan yang diberikan. Pelayanan fisik dan non fisik dalam hal ini staf front liner (satpam, teller, customer service) termasuk kecepatan pelayanan, berpengaruh pada persepsi pelanggan terhadap bank. Survey Mc Kinsey tentang personal financial service, juga membenarkan bahwa nasabah di Indonesia semakin canggih. Alasannya, mereka sangat loyal dengan banknya dan sangat puas dengan pelayanan banknya. Tapi mereka tetap mau pindah ke bank lain jika bank lain memberikan pelayanan yang sesuai dengan keinginannya (Majalah Info Bank,
2003:15). Tren saat ini adalah pelanggan menggunakan layanan jasa ataupun membeli produk dari sebuah perusahaan karena servicenya.

Konsumen semakin kritis dengan kualitas produk dan mutu layanan yang diberikan oleh bank. Pemberitaan mengenai rendahnya kualitas layanan dengan mudahnya akan tersebar ketika ada sistem pelayanan yang mengecewakan di bank tertentu, seperti kasus pengoperasian ATM (Automatic Teller Machine) yang sering rusak, antrian yang panjang, petugas yang tidak ramah, hingga produk yang tidak sesuai dengan harapan pelanggan. Lewat obrolan di masyarakat dan peranan pers yang semakin bebas semakin memudahkan pemberitaan tersebut menjadi opini publik.

Pemahaman publik terhadap sebuah perusahaan akan menimbulkan image/ citra. Citra positif untuk memperoleh saling pengertian merupakan hal yang tidak bisa dihindarkan dan menjadi fungsi strategis public relations (PR). Good image atau citra yang baik sangat mempengaruhi kelangsungan hidup sebuah perusahaan. Oleh karena itu, citra perusahaan harus dipersepsi baik oleh publik dengan melakukan kegiatan hubungan pelanggan yang baik pula.

Customer Relations Management atau manajemen hubungan pelanggan yang baik sangatlah penting mengingat keberadaan perusahaan ditentukan sekali oleh kepuasan pelanggan atas layanan yang diberikan, terutama pada perusahaan yang profit oriented seperti bank yang kelangsungan hidupnya ditentukan oleh nasabah. Hubungan yang harmonis dimaksudkan untuk mengikat perhatian, pengertian, kepercayaan, dukungan, tanggapan/respon konsumen 
agar tetap menjadi nasabah yang loyal. Jadi, manajemen hubungan pelanggan merupakan simpul paling penting karena disinilah kontak terjadi.

\section{Public Relations Jasa Perbankan}

Setiap perusahaan tidak dapat melepaskan diri dari fungsinya sebagai komunikator. Dan fungsi ini dapat dilakukan oleh public relations yang mempunyai peran penting dalam membina hubungan baik antara perusahaan dengan publik yang dituju. Seperti definisi public relations, "Public relations practice is the planned and sustained effort to establish and maintain goodwill and mutual understanding between an organization and its public" (Jefkins, 1994:7). Mengandung pengertian bahwa public relations dianggap sebagai alat atau medium untuk menciptakan hubungan dengan siapa saja yang dapat membawa keuntungan dan kemajuan dalam organisasi/lembaga yang bersangkutan. Sebagai jembatan antara organisasi dengan publiknya agar terjadi hubungan yang harmonis.

Keberadaan public relations seperti yang diungkapkan F. Rachmadi (1996:21) bahwa, "Public relations menumbuhkan dan mengembangkan hubungan baik antara lembaga/organisasi dengan publiknya, intern maupun ekstern dalam rangka menanamkan pengertian, menumbuhkan motivasi dan partisipasi publik dalam upaya menciptakan iklim pendapat (opini publik) yang menguntungkan lembaga/ organisasi. Hubungan publik internal yaitu hubungan dengan karyawan dan stakeholders dan hubungan publik eksternal yaitu hubungan dengan pelanggan, khalayak sekitar, instansi pemerintah, pers (F. Rachmadi, 1996:121). Hubungan dengan publik dalam tulisan ini lebih menitikberatkan pada publik eksternal yaitu hubungan dengan pelanggan (customer relations) yang diwakili oleh public relations dalam rangka mengkomunikasikan segala sesuatu guna tercipta pengertian bersama.

Salah satu tujuan keluar public relations (external public relations) adalah mempererat hubungan dengan orang-orang atau instansi-instansi di luar organisasi/perusahaan (publik), demi terciptanya opini publik yang menguntungkan organisasi/perusahaan itu. Tugasnya adalah mengadakan komunikasi dua arah yang sifatnya informatif dan persuasif kepada publik luar. Karena salah satu karakteristik fundamental dari sebuah hubungan yang bekerja dengan baik adalah komunikasi dua arah (Rachmadi, 1996:153). Telah banyak kita jumpai di kehidupan seharihari dalam situasi dan tempat manapun, bahwa ketika komunikasi terhambat kemungkinan hubungan tersebut akan memburuk.

Komunikasi secara mendasar dapat didefinisikan oleh Hovlan, Janis dan Kelly seperti yang dikutip Jalaludin Rahmat, "The process by which an individual (the communicator) transmite stimult (usually verbal) to modify the behavior of other individuals (the audience), yang terjemahannya kurang lebih bahwa komunikasi merupakan proses dimana seseorang (komunikator) mengirimkan stimulus biasanya berbentuk verbal untuk mengubah perilaku orang lain (Rahmat, 1989:3). Untuk jasa perbankan, seringkali menggunakan situasi hubungan pelanggan tatap muka. Dimana melibatkan serangkaian interaksi yang lebih luas bagi kebanyakan pelanggan, interaksi tersebut tidak bersifat pribadi dan tidak melibatkan penyingkapan informasi pribadi 
(Rahmat, 1989:159). Dapat dikatakan bahwa komunikasi di dunia bisnis jasa perbankan membutuhkan interaksi dengan orang lain dengan tujuan agar terjadi perubahan sikap pada konsumen, sehingga diperlukan sebuah bentuk komunikasi yang bersifat timbal balik dan lebih persuasif. Hal ini menuntut public relations di dunia bisnis perbankan selalu berinteraksi dan berkomunikasi dengan nasabah maupun mitra usahanya.

Komunikasi mempunyai peranan penting kaitannya dengan pelayanan pelanggan. Misalnya pada bagian pengecekan kredit, tagihan-tagihan, menjawab telepon dari konsumen, maupun penanganan masalah-masalah yang berkaitan dengan pengaduan dari konsumen. Kegiatan-kegiatan tersebut dengan sendirinya menggunakan banyak komunikasi. Dalam hal ini, komunikasi eksternal yang terjadi antara perusahaan dengan pelanggannya dilakukan secara dua arah baik dalam bentuk formal maupun non formal.

Kondisi persaingan pasar yang tidak menentu dan fluktuatif menuntut praktisi PR untuk memperhatikan pelanggannya. Fokus perhatian dari hubungan pelanggan bagi perusahaanyang bergerak di bidang layanan jasa perbankan adalah memberikan pelayanan yang prima (service of excellence) dan mengutamakan kepentingankonsumen(customeroriented). Pengertian dari service of excellence adalah berkaitan dengan jasa pelayanan yang dilaksanakan oleh perusahaan dalam upaya untuk memberikan rasa kepuasan, dan menumbuhkan kepercayaan terhadap pihak pelanggannya (customer), sedangkan customer tersebut merasa dirinya dipentingkan atau diperhatikan dengan baik dan wajar (Ruslan, 2001:245). Jadi, selain meningkatkan hubungan pelanggan dengan komunikasi, perusahaan harus menyatakan kepeduliannya pada pelanggan.

Persaingan di bidang layanan jasa perbankan kini sudah merambah ke wilayah yang paling dalam, yaitu bagaimana memikat hati nasabah dengan memberikan pelayanan yang prima. Penyediaan layanan on line, fasilitas ATM hingga debit card sebagai bukti untuk memberikan layanan terbaik. Faktor pelayanan merupakan aspek penting bahkan boleh dikatakan ia menjadi tulang punggung sukses tidaknya sebuah bank. Bank-bank berlomba berupaya seoptimal mungkin untuk memberikan layanan terbaik bagi nasabahnya.

Survei yang dilakukan Marketing Research Indonesia (MRI) pada tanggal 24 Agustus 2002 sampai dengan 24 Januari 2003 terhadap 21 bank yang ada di Jakarta dan Surabaya, rata-rata performa pelayanannya meningkat tipis yakni dari 68,53 pada survei sebelumnya, menjadi 69,76\% pada survei terakhir (Majalah Info Bank, 2003:22). Dinamika pelayanan prima 21 bank tersebut untuk performa seluruh pelayanan dalam peringkat 10 besar adalah (1) Bank Niaga, (2) Bank Danamon, (3) Hongkong and Shanghai Banking Corporation (HSBC), (4) Bak Mega, (5) Citibank, n.a., (6) Bank Bukopin, (7) Bank NISP, (8) Standar Chartered (Stanchart) Bank, (9) ABN-AMRO Bank, dan (10) Bank Central Asia (BCA).

Jadi, keberadaan PR di perusahaan jasa perbankan berfungsi sebagai garda depan perusahaan yang diharapkan dapat memberikan pelayanan dan memuaskan nasabah secara konsisten (terus-menerus). Harus berangkat dari kaidah bahwa kepuasan adalah segalagalanya bagi nasabah. Menentukan hubungan dengan pelanggan (customer relations) yang terjalin dengan baik adalah 
dasar dari public relations. Hubungan itu dapat dimulai dari kepuasan pelanggan yang dihasilkan oleh produk atau layanan yang baik. Kepuasan pelanggan dengan sendirinya menciptakan reputasi yang baik dan mendorong rekomendasi. Tetapi kepuasan itu harus dijaga, dipelihara dan dipertahankan melalui public relations (Jefkins, 1994:151). Sehingga seorang pejabat PR dituntut memiliki service oriented yang bagus dan willing to serve.

\section{Customer Relations Management (CRM)}

Gejala yang muncul pada aktivitas bisnis saat ini lebih berorientasi pada konsumen atau pelanggan (customer oriented) bukan pada produknya (product oriented). Oleh karena itu, untuk mengelola pelanggan secara baik adalah hal yang sangat penting bagi perusahaan untuk berpikir dalam kerangka "customer oriented". Sesuai dengan bahasan tulisan ini yaitu perusahaan jasa perbankan yang hendaknya selalu memikirkan apa yang dibutuhkan nasabah, apa yang diinginkan nasabah, dan pelayanan yang bagaimana disenangi oleh nasabah, sehingga nantinya nasabah tidak hanya merasa puas tetapi juga loyal, kembali dan kembali berhubungan dengan bank kita.

Konsumen (customer) bagi perusahaan yang bergerak di bidang industri jasa perbankan merupakan hal yang sangat penting. Artinya tanpa konsumen dalam hal ini adalah nasabah yang menggunakan produk dan jasa layanan bank, perusahaan tidak memiliki arti apa-apa. Nasabah merupakan fokus utama perusahaan. Nasabah adalah urat nadi operasi perusahaan. Sehingga kesetiaan nasabah merupakan aset yang paling berharga.
CRM adalah suatu sarana untuk membentuk hubungan perusahaan dengan konsumen. Manajemen ini menciptakan suatu revolusi mengenai bagaimana bisnis dilakukan di seluruh bagian perusahaan. Menggambarkan suatu strategi yang menempatkan konsumen di jantung segala sesuatu yang dilakukan oleh perusahaaan. CRM mengakui bahwa setiap konsumen adalah individu-individu yang memiliki kebutuhan, aspirasi dan keinginan. Dengan mengakui konsumen sebagai individu, suatu perusahaan dapat mulai memperlakukan mereka dengan cara bagaimana mereka ingin diperlakukan (Moore dan Moore, 2005: 4).

Jadi dapat dikatakan bahwa CRM merupakan mekanisme membangun sebuah hubungan antara bank dengan nasabah. CRM memiliki kemampuan untuk memungkinkan bank memahami perilaku pembelian nasabah dengan lebih baik, atau paling tidak memahami hal-hal lain yang dapat diperoleh, dan untuk menentukan tipe komunikasi yang harus dijalin bank dengan nasabah. CRM menjadi semakin penting bagi semua perusahaan jasa perbankan yang ingin memberikan layanan yang lebih baik kepada nasabah dengan biaya yang cukup rendah tentunya.

Manajemen Hubungan pelanggan diperkuat dengan konsep 4R dari pemasaran, yaitu Retention, Relationship, Referrals dan Recovery (Ketahanan, Hubungan, Perekomendasian dan Pemulihan). Alurnya dapat dilihat dalam gambar di bawah ini (Barnes, 2003:28). 


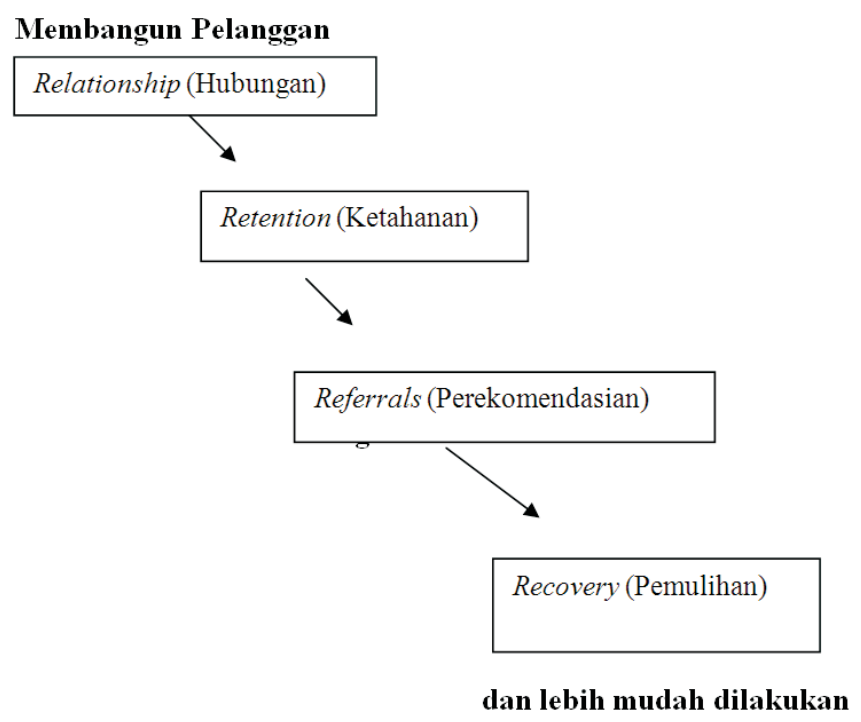

\section{Gambar 1. 4R dari Pemasaran}

Dari gambar 1 tersebut, dapat dipahami bahwa hubungan terjadi ketika nasabah secara sukarela atau bahkan secara antusias melakukan bisnis dengan sebuah bank dalam jangka waktu yang lama. Ketahanan adalah bagaimana mempertahankan nasabah yang kita inginkan dengan memenuhi dan memuaskan kebutuhan mereka. Perekomendasian merujuk pada efek penyebaran berita dari mulut ke mulut yang merupakan hasil dari kepuasan nasabah. Pemulihan dari pelayanan yang buruk pada nasabah haruslah menjadi sebuah komponen penting dalam mengelola hubungan pelanggan.

Kesalahan yang mungkin terjadi adalah fakta dalam kehidupan dan bisnis yang tidak bisa dihindari. Hal yang tak terduga tentu akan dijumpai dalam aktivitas bisnis apapun. Akan tetapi, kesalahan dapat diubah menjadi kesempatan untuk membuat pelanggan terkesan dan tetap setia dengan menegaskan kembali komitmen perusahaan dan kesungguhan untuk melayani dan memuaskan pelanggan. Kesungguhan dari pihak bank meng-handle segala macam bentuk permasalahan yang dialami nasabah menunjukkan komitmen untuk melayani dan memuaskan nasabah. Jangan sampai nasabah menjadi kecewa dan frustasi karena menunggu proses penanganan masalahnya. Hal ini diperkuat oleh pendapat Steve Duck bahwa dua faktor kunci sebagai hal yang vital untuk mempertahankan suatu hubungan adalah komitmen dan kepercayaan (Barnes, 2003:147).

Hubungan menurut Steve Duck adalah "Proses yang amat rumit dan panjang dengan banyak jebakan dan tantangan. Hubungan tidak begitu saja terjadi; itu harus dimulai, dilaksanakan, dikembangkan, dijaga agar tetap berlangsung baik dan jangan sampai menjadi masam. Perlu dikelola secara hati-hati dan selalu membutuhkan keahlian dari orang-orang yang terlibat" (Barnes, 2003:146). Hubungan pelanggan mengimplikasikan bahwa sifat dari hubungan perusahaan dengan pelanggan ditentukan oleh apa yang diterima pelanggan sebagai balasannya (Barnes, 2003:154). Mengandung pengertian bahwa hubungan yang penting bagi kedua belah pihak dan ingin diteruskan oleh keduanya, haruslah memberikan keuntungan timbal balik bagi kedua 
belah pihak. Sekali suatu hubungan dibentuk, harus dilakukan usaha keras untuk mempertahankan hubungan tersebut sebagai suatu hubungan yang sehat, hidup, dan bersatu.

Banyak faktor lain yang terkait dengan penciptaan dan pemeliharaan hubungan yang dekat. Faktor lain yang biasanya diasosiasikan dengan daya tarik partner dari suatu hubungan adalah kemudahan dan frekuensi dalam berinteraksi, keakraban (perasaan dekat, keramahan, jarak yang dekat), kesamaan (memiliki nilai, sikap, dan perspektif yang sama), kebersamaan (memiliki tujuan yang sama dan merasa berada dalam satu kesatuan), dan saling bergantung (perasaaan bergantung pada pihak lain untuk mencapai suatu tujuan tertentu). Beberapa dari dimensi hubungan ditampilkan dalam gambar 2 (Barnes, 2003:157).

\begin{tabular}{|l|l|}
\hline - Kepercayaan, etika & Ketergantungan \\
- Komitmen & - Kesadaran akan riwayat pihak lain \\
- Kedekatan & - Komunikasi dua-arah \\
- Pengertian, empati & - Kehangatan, keintiman \\
- Tujuan yang sama & - Minat pada kebutuhan \\
- Nilai yang dibagikan & - Pengetahuan \\
- Hubungan timbal balik & - Responsif \\
- Rasa hormat, ketulusan & - Menepati janji \\
- Perhatian, kasih sayang, rasa suka & - Kompetensi \\
\hline
\end{tabular}

\section{Gambar 2. Dimensi-Dimensi Hubungan Steve Duck}

PentingnyaCRMbagiperusahaanjasa perbankan adalah untuk mendapatkan informasi tentang pelanggan mengenai produk atau jasa yang telah mereka gunakan. Apakah pelayanan kepada nasabah sudah melebihi apa yang dapat diberikan sehingga nasabah merasa puas? Seorang pelanggan merasa puas jika kebutuhannya, secara nyata atau hanya anggapan, terpenuhi atau melebihi harapannya (Gerson, 2002:5). Jadi kepuasan nasabah adalah bila sebuah produk atau jasa memenuhi atau melampaui harapan pelanggan. Merupakan penilaian mengenai apakah hasil penggunaan layanan jasa perbankan sudah memenuhi atau melampaui harapan nasabah.

Sejalan dengan tujuan dari kebijaksanaan customer relations management yaitu meyakinkan pelanggan dan calon pelanggan bahwa produk atau jasa perusahaanakan terus ditingkatkan mutu, macam dan kegunaannya, menyediakan sumber penyediaan yang konsisten dengan suatu kebijaksanaan harga konstruktif yang rasional, melayani para pelanggan dengan jujur, dan berusaha mengembangkan perusahaannya serta pasaran konsumennya (Barnes, 2003:173). Sehingga perusahaan jasa perbankan harus memaksimumkan pengalaman nasabah yang menyenangkan dan meminimumkan atau meniadakan pengalaman nasabah yang kurang menyenangkan. Pada akhirnya kepuasan nasabah dapat menciptakan kesetiaan atau loyalitas kepada perusahaan yang memberikan mutu pelayanan yang memuaskan. 
Fokusperhatianbisnisjasa perbankan adalah kualitas jasa. Karena produk yang dihasilkan berupa pelayanan. Kualitas jasa yang tinggi dapat menyebabkan organisasi atau perusahaan mengurangi tingkat kesalahan, pemborosan dan ketidakpuasan pelanggan. Perusahaan jasa dan pelayanan lebih menekankan pada kualitas proses, karena konsumen biasanya terlibat langsung dalam proses tersebut. Sedangkan perusahaan yang menghasilkan produk lebih menekankan pada hasil karena konsumen pada umumnya tidak terlibat secara langsung dalam prosesnya.

Proses pelayanan terbaik pada pelanggan dan tingkat kualitas dapat dicapai secara konsisten dengan memperbaiki pelayanan dan memberikan perhatian khusus pada standar kinerja pelayanan baik standar pelayanan internal maupun standar pelayanan eksternal. Semakin disadari bahwa mutu pelayanan dan kepuasan pelanggan merupakan aspek penting dalam suatu perusahaan jasa perbankan.

Permasalahan yang sering kita jumpai dalam kegiatan pelayanan di sebuah bank yaitu pada saat kondisi ramai pengunjung yang menyebabkan nasabah harus antri dan menunggu lama, nasabah merasakan pelayanan yang tidak sesuai dengan harapan mereka. Hal ini tentunya menimbulkan kekecewaan dan ketidakpuasan. Hal ini perlu segera diperhatikan oleh pihak bank yang diwakili oleh Public Relations Officer-nya dan petugas front liner -nya. Mereka harus dengan sigap dan cepat merespon setiap permasalahan yang terjadi dengan memberikan solusi yang baik.

Jangan sampai hanya karena permasalahan sekecil apapun, nasabah berpaling ke bank lain karena merasakan ketidakpuasan dalam kegiatan pelayanannya. Kesan negatif yang dirasakan oleh nasabah akan dengan cepat tersebar pada masyarakat lainnya. Hal ini merupakan salah satu akar kegagalan perusahaan dalam pelaksanaan CRM. Ketidakpuasan yang dirasakan oleh nasabah harus segera diperbaiki, sebab apabila hal ini sampai didengar orang lain akan berakibat tidak baik bagi kehidupan perusahaan jasa perbankan itu sendiri.

Seperti kegiatan CRM yang dilakukan oleh PR Bank Syariah Mandiri Cabang Solo bersama petugas front liner yang mengungkapkan beberapa fakta antara lain:

1. PR dan petugas front liner memberikan pelayanan dan memuaskan nasabah secara konsisten (terus-menerus) melalui sikap ikhlas melayani yang dimiliki karyawan Bank Syariah Mandiri yang merupakan jiwa dan semangat berbagi dalam mewujudkan pelayanan prima.

2. PR dan petugas front liner selalu meningkatkan pengetahuannya (uggrading) tentang perbankan syariah. Agar didalam memberikan penjelasan kepada nasabah tidak menimbulkan persepsi-persepsi yang bermacammacam.

3. PR dan petugas front liner diwajibkan mempunyai kesadaran mengenai aspekkepuasan pelanggan. Bagaimana melayani nasabah dari awal pelanggan datang sampai meninggalkan kantor. Bagaimana menghandle permasalahan dan keluhan dengan tindakan yang solutif dan memberikan rasa nyaman. Memberikan pelayanan yang mengena di hati nasabah dengan menciptakan layanan yang sesuai dengan kebutuhan nasabah.

4. PR dan petugas front liner dalam melakukan kegiatan hubungan pelanggan menampilkan pelayanan yangbaikdenganlebihmemperhatikan 
service attitudenya. Berusaha untuk tidak mengecewakan nasabah dan membuat nasabah nyaman dan percaya untuk tetap bermitra dengan Bank Syariah Mandiri Cabang Solo.

5. PR selalu berkoordinasi dengan staf front liner dan juga bagian back office dalam memberikan pelayanan dan menghandle segala permasalahan nasabah. Mengubah anggapan mengidentifikasi pekerjaan dan tanggung jawab sendiri ("saya seorang public relations) dengan lebih mengidentifikasi tujuan utama tim ("kami tim front liner maupun back office bekerja bersama untuk melayani pelanggan yang membutuhkan pelayanan bank dalam transaksi keuangan"). Sehingga diharapkan dalam kondisi apapun tidak lagi dijumpai nasabah yang harus menunggu lama untuk dilayani.

6. Seluruh karyawan Bank Syariah Mandiri Cabang Solo berupaya mengembangkan sinergi, menyamakan visi-misi, memperkuat sikap dan tanggung jawab bersama yang terwujud dalam kinerja pelayanan menuju perbaikan yang berkelanjutan untuk kelangsungan keberadaan Bank Syariah Mandiri Cabang Solo ke depan.

7. PR secara kontinyu dan lebih intensif menyampaikan informasi tentang perbankan syariah yang masih belum begitu familiar di masyarakat, terkait informasi tentang: produk, visi, misi, serta apa dan bagaimana Bank Syariah Mandiri itu sendiri (Mahanani, 2003:150).

Dari contoh kasus di atas, dapat ditarik kesimpulan bahwa kegiatan CRM yang dilakukan PR Bank Syariah Mandiri Cabang Solo bersama petugas front linernya memperlihatkan bahwa interaksi yang dilakukan tidak hanya berorientasi pada penjualan produk jasa perbankan saja, tetapi juga mengedepankan performance pelayanan maksimal yang muncul dari karyawan yang ramah, pemberian informasi yang jelas dan terbuka. Usaha untuk memuaskan nasabah dengan memberikan pelayanan terbaik tidak hanya PR saja yang bertanggung jawab, melainkan seluruh pihak yang terkait dengan bank tersebut.

\section{Good Image}

Citra mempesentasikan dari seluruh persepsi terhadap suatu obyek dan dibentuk dari informasi dan pengalaman di masa lalu terhadap oyek tersebut. Artinya persepsi disini sebagai hasil pengamatan terhadap unsur lingkungan yang dikaitkan dengan suatu proses pemaknaan. Dengan kata lain, individu akan memberikan makna tehadap rangsang berdasarkan pengalamannya mengenai rangsang. Kemampuan mempersepsi itulah yang melanjutkan proses pembentukan citra (Soemirat dan Ardianto, 2003:116). Citra sebagai jumlah dari gambaran-gamaran, kesan-kesan, dan keyakinan-keyakinan yang dimiliki oleh seseorang terhadap suatu obyek (Sutisna, 2003:83). Beberapa dimensi dari citra yaitu integritas, kualitas, inovasi teknik, keahlian, pelayanan, kepercayaan, tanggungjawab sosial, dan imajinasi (Yeshin, 1998:191).

Good image merupakan sasaran dari public relations. PR berupaya untuk menciptakan citra yang baik (good image) dan membangun kepercayaan (trust) untuk memperoleh saling pengertian publik terhadap perusahaan. Kepercayaan nasabah menjadi faktor utama bagi perbankan untuk tetap bertahan. Bagaimana nasabah dan publik melihat dan menilai perusahaan jasa perbankan, itulah yang tercermin dari 
citranya. Sehingga menjadi hal yang sangat penting bagi perusahaan jasa perbankan untuk tetap mempunyai citra yang baik di mata nasabahnya. Good image menjadi kunci bagi perusahaan jasa perbankan untuk dapat mendapat kepercayaan dari pelanggannya.

Citra yang baik memang benarbenar dapat menentukan keberhasilan keberadaan sebuah bank. Sehingga PR harus benar-benar cerdas membuat bank tersebut disukai dan dipercaya oleh siapa pun. Tanpa adanya kepercayaan, maka apapun itu namanya tidak akan mampu untuk bertahan lama. Jika pencitraan yang dilakukan sesuai dengan kenyataan dan tidak ada unsur untuk melebihlebihkan, tentu akan semakin menambah kepercayaan nasabah pada bank.

Citra PR yang ideal adalah kesan yang benar, yakni sepenuhnya berdasarkan pengalaman, pengetahuan, serta pemahaman atas kenyataan yang sesungguhnya. Itu berarti citra tidak seyogianya "dipoles agar lebih indah dari warna aslinya", karena hal itu justru dapat mengacaukannya. Suatu citra yang sesungguhnya bisa dimunculkan kapan saja, termasuk di tengah terjadinya musibah atau sesuatu yang buruk. Caranya adalah dengan menjelaskan secara jujur apa yang menjadi penyebabnya, baik itu informasi yang salah atau suatu perilaku yang keliru (Anggoro, 2001:69). Kejujuran yang dilakukan oleh praktisi PR adalah kejujuran dalam menyampaikan fakta baik itu negatif ataupun positif. PR harus menyampaikan fakta yang sebenarnya tentang banknya tersebut tanpa unsur melebih-lebihkan ataupun menguranginya.

Menciptakan citra yang tidak sesuai dengan fakta yang ada, pada dasarnya tidak sesuai dengan hakikat PR itu sendiri. Karena pekerjaan PR selalu berdasarkan fakta dan data. Kalaupun ada keuntungan yang didapatkan dari kebohongan yang dilakukan, maka itu tidak ada artinya bila dibandingkan dengan kerugian jangka panjang yang akan ditimbulkannya. Dengan kebohongan sedikit saja yang dilakukan oleh PR maka itulah titik awal kehancuran sebuah perusahaan. Sehingga usaha menciptakan dan perbaikan citra yang dilakukan oleh perusahaan jasa perbankan harus didasarkan pada realitas yang sebenarnya.

Sukatendel mengungkapkan bahwa citra itu dengan sengaja perlu diciptakan agar bernilai positif. Citra itu sendiri merupakan salah satu aset terpenting dari perusahaan (Soemirat dan Ardianto, 2003:122). Jadi, citra menjadi kunci bagi perusahaan jasa perbankan untuk dapat meraih nasabah yang besar dan mempertahankannya. Merupakan salah satu strategi jitu untuk merebut dan mempertahankan nasabah dan stakeholders lainnya.

Citra yang baik pada gilirannya akan menciptakan persepsi yang baik pula. Persepsi ini dapat mempengaruhi seorang nasabah dalam mengambil keputusan untuk memilih menggunakan jasa perbankan tertentu. Berdasarkan pengamatanyang dilakukan oleh Ashadi Siregar dan Rondang Pasaribu (2000:44) bahwa kecenderungan yang berkembang belakangan ini menunjukkan citra korporasi atau perusahaan di mata masyarakat turut berpengaruh terhadap keputusan mereka dalam memilih suatu jasa atau produk yang ditawarkan.

Diperkuat dengan pendapat Tony Yeshin (1998:83) yang mengatakan in many purchase situations, company recognition and image are important in the decision making process (dalam situasi pembelian kerap kali pengenalan dan citra produsen adalah faktor yang penting dalam proses pembuatan keputusan). Demikian juga Rhenald Kasali menuliskan hasil riset terhadap perilaku konsumen yang 
menunjukkan bahwa ada sejumlah alasan mengapa konsumen bersedia membeli, salah satunya diantaranya adalah reputasi dan citra produsen (Kasali, 2003:151). Dapat dipahami bahwa pertimbanganpertimbangan yang dilakukan nasabah untuk menggunakan pelayanan jasa perbankan tertentu dipengaruhi oleh citra bank tersebut.

Bank dengan citra yang baik akan lebih memungkinkan untuk tetap bertahan dan eksis. Citra bank yang baik adalah faktor penting bagi nasabah untuk melakukan pembuatan keputusan menjadi nasabah bank tersebut. Selain karena alasan pelayanannya yang bagus, aman, suku bunga yang rendah, akseptabilitas dan jaringannya bagus, kemudahan dalam bertransaksi, biaya adminstrasi rendah, fasilitas ATM yang luas, keberadaan kantor cabang yang banyak, beragam hadiah yang diberikan, dan beberapa alasan lainnya, tetap citra bank yang bersangkutan menjadi alasan utama bagi nasabah untuk melakukan keputusan bertransaksi.

Kondisi persaingan yang ketat di bisnis jasa perbankan ini menuntut perusahaan bisa memberikan pencitraan yang baik melalui penyediaan layanan yang lengkap untuk pelanggannnya. Ketika nasabah mempunyai pengalaman yang baik atas penggunaan layanan yang disediakan maka nasabah mempunyai citra yang positif atas bank tersebut. Dengan demikian, nasabah bisa menjadi pelanggan yang loyal dengan melakukan perekomendasian kepada orang lain. Karena orang pada umumnya lebih mungkin mencoba sesuatu yang baru jika hal tersebut direkomendasikan oleh kolega, teman, atau anggota keluarga yang dapat dipercaya. Jadi tidak hanya nasabah tersebut yang menjadi pelanggan kita namun juga teman dan anggota keluarga yang mereka bawa.

\section{Simpulan}

CRM sebagai salah satu bentuk ikhtiar perusahaan jasa perbankan untuk selalu memberikan pelayanan yang terbaik kepada nasabahnya. Manajemen ini mencakup segala sesuatu yang berhubungan dengan pelanggan. Bermanfaat bagi pihak bank untuk mendapatkan informasi tentang pelanggan mengenai produk atau jasa yang telah mereka gunakan. Apabila ada hal-hal yang mengecewakan nasabah pada pelayanan perbankan, segera dapat diatasi sehingga tidak akan memberikan pengaruh besar pada pencitraan. Sebaliknya apabila hubungan dengan nasabah tidak diatur secara baik akan menimbulkan opini publik yang tidak diinginkan perusahaan.

Strategi CRM perlu dikembangkan untuk pencapaian citra baik sebuah bank yang nantinya akan berdampak pada tingkat penjualan jasa. Membuat konsumen tidak hanya merasa berharga, tapi juga tahu bahwa mereka dihargai dan keinginan mereka dicukupi serta aspirasi mereka dipenuhi. Kesetiaan nasabah menjadi prioritas utama bagi pihak bank. Sehingga peningkatan dan perbaikan pelayanan kepada nasabah terus menerus dilakukan untuk tetap menjaga kelangsungan hidup bank selanjutnya.

Mempunyai citra baik yang powerful merupakan aset berharga bagi bank untuk meraih perhatian masyarakat. Hal ini tentu merupakan salah satu jalan yang bisa dilakukan agar nasabah semakin tertarik denganbankkita. Pelayanan yang diberikan haruslah menjanjikan penyelesaian problem nasabah dan membawa kesenangan/ kepuasan di hati nasabah.

Pembentukan good image tidaklah semudah membalikkan telapak tangan. Untuk itu diperlukan customer relations management yang baik pula dengan 
memposisikan bank dan segala produk jasa dan pelayanannya memiliki kemampuan untuk menciptakan hubungan yang lebih kuat dengan nasabah. Karena citra terkait penilaian baik atau buruk dari masyarakat.

Citra baik merupakan sesuatu yang sangat penting untuk menentukan bagus tidaknya tanggapan masyarakat terhadap sebuah bank. Bisa dikatakan, citra baik merupakan jantung yang akan menentukan masa depan bank tersebut. Apakah citra baik bank benarbenar mampu merebut hati pelanggan untuk menjatuhkan pilihan pada bank yang bersangkutan ataukah tidak. Hal ini semakin dikuatkan dengan kesan masyarakat umum bahwa pelayanan yang memuaskan dan CRM yang baik dapat dijadikan sebagai salah satu ukuran bagus tidaknya citra sebuah bank.

Dalam kondisi seperti ini, bisa dikatakan bahwa citra baik merupakan hal terpenting yang menjadi penentu awal tertariknya orang pada sebuah bank. Jika pelayanan yang diberikan hanya asalasalan saja tanpa mempertimbangkan berbagai hal yang akan dialami selanjutnya, maka jangan salahkan nasabah jika meninggalkan bank kita dan berpindah ke bank lain yang lebih menjanjikan pelayanan yang sempurna (excellence). Karena usaha untuk menciptakan citra perusahaan yang baik sangat membutuhkan waktu yang lama, sedangkan usaha untuk menghancurkan citra hanya membutuhkan waktu dalam hitungan detik saja.

\section{DAFTAR PUSTAKA}

Anggoro, M. Linggar (2001). Teori $\mathcal{E}$ Profesi Kehumasan. Jakarta: Bumi Aksara. 2001.

Ardianto, Ardianto dan Soemirat, Soleh
(2013). Dasar-Dasar Public Relations. Bandung: PT. Remaja Rosdakarya.

Barnes, James G. (2003). Secrets of Customer Relations Management. Yogyakarta: Penerbit Andi

Gerson, Richard F. Ph.D. (2002). Mengukur Kepuasan Pelanggan. Jakarta: Penerbit PPM.

Jefkins, Frank (1989) Public Relations Tehcnique. New York: Heinnemen Publishing. . (1994). Public Relations Untuk Bisnis. Jakarta: Pustaka Binaman Pressindo.

Khasali, Rhenald (1999). Manajemen Public Relations. Jakarta: Pustaka Utama Grafiti.

Mahanani, Prima Ayu Rizqi (2003), Costumer Relations dan Costumer Satisfaction (Studi Korelasi antara Mutu Pelayanan Customer Service Bank Syariah Mandiri Cabang Solo dengan Tingkat Kepuasan Pelanggan). Solo: FISIP-UNS.

Moore, Patricia Moore \& William (2005). Menguasai CRM (Manajemen Hubungan Konsumen) dalam Seminggu. Jakarta: Prestasi Pustaka.

Pasaribu, Ashadi Siregar dan Rondang (2000). Bagaimana Mengelola Media Korporasi-Organisasi. Yogyakarta Kanisius.

Rachmadi, F. (1996). Public Relations dalam Teori dan Praktek. Aplikasi dalam Badan Usaha Swasta dan Lembaga Pemerintah. Jakarta: Gramedia Pustaka Utama. 1996.

Rosady, Ruslan (2001). Manajemen Humas dan Manajemen Komunikas. Jakarta: Raja Grafindo Persada.

Sutisna (2003). Perilaku Konsumen $\mathcal{E}$ Komunikasi Pemasaran. Bandung: PT. Remaja Rosdakarya.

Yashin, Tony (1998). Marketing Communications Strategy. Oxford: Butterwoth-Heinemann

Majalah InfoBank, No. 289, Edisi Juni 2003. 